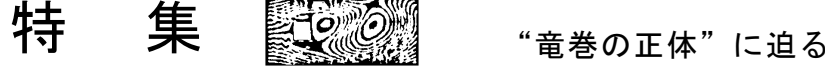

\section{竜巻の発生環境と生成メカニズム \\ Meteorological environment for tornado outbreak and mechanism of tornadogenesis}

\author{
佐々浩司*1 鈴木 修*2 小林文明*3
}

Koji SASSA, Osamu SUZUKI, Fumiaki KOBAYASHI

\section{1. はじめに}

突発的に発生し，大きな被害をもたらす竜巻に対する 予報やナウキャストのためには，その気象学的な発生環 境を明らかにすることと，生成メカニズムを明らかにす ることが必要である。このため多くの観測的研究 1-3)や, 気象モデルによるシミュレーション 4-9)が行われてきた。 これらを通して強い竜巻をもたらすことの多いスーパー セルの発生環境や，それによる竜巻生成メカニズムが明 らかにされ，日本でも竜巻注意情報の発表が行われるよ うになってきた。一方，日本において発生することの多 い非スーパーセル竜巻 10)の発生環境については, その規 模が比較的小さいことや親雲がスーパーセルのような特 徵的な対流雲とは限らないことなどもあって十分に明ら かにされてはいない。

ここでは，発生環境や生成メカニズムのさらなる理解 を進めるために進行中の観測プロジェクトや観測事例, 気象モデルによる高解像度解析, 室内実験の成果などを 紹介しつつ，今後の課題について言及する。

\section{2. 竜巻の発生環境に関連するパラメータ}

過去の研究から，竜巻には発生しや寸い環境があるこ とが知られている 11,12)。とくに，強い竜巻をもたらすこ との多いスーパーセルという特殊な積乱雲が発達寸る環 境は, 不安定な大気成層と強い風の鉛直シアーによって 特徵付けられることが知られている ${ }^{13)}$ 。スーパーセルは 内部にメソサイクロンと呼ばれる小低気圧を持つ発達し た積乱雲である。ここで，「環境」を定量的に把握するた め, 大気の不安定の程度を示寸指標である CAPE

(Convective Available Potential Energy) やK-インデ ックスと呼ばれる指標, 風の鉛直シアーの情報を与える

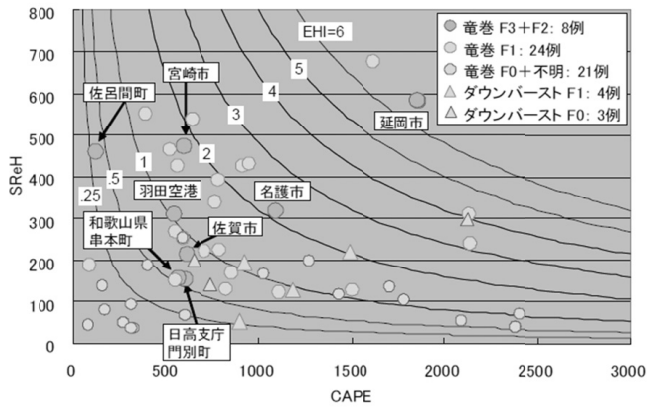

図 1 竜巻及びダウンバースト事例における $\mathrm{CAPE}, \mathrm{SRH}, \mathrm{EHI}{ }^{19}$

地上から $3 \mathrm{~km}$ までの風ベクトルのシアーやストームに 相対的なへリシティー $\left(\mathrm{SRH}^{14,15}\right)$ または $\left.\mathrm{SReH}\right)$ ，ある いは, それらを組み合わせた指標である EHI ${ }^{14) や T V P 16), ~}$

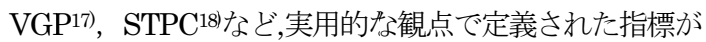
利用される (主な指標の定義は付録参照)。図 1 は過去に 発生した竜巻等突風の事例について海老原・㴰下 ${ }^{19)}$ の求 めた発生時刻前後 1 時間以内で発生地点を中心とする $50 \mathrm{~km}$ 四方内の CAPE,SRH,EHI の最大值である。F1 以 上の竜巻の多くが，大きな $\mathrm{SRH}$ と $\mathrm{CAPE}$ の領域で発生 していることが分かる。図中の曲線は, CAPE と SRH の積を 16000 (正規化のための係数) で割った指数であ る $\mathrm{EHI}$ の等值線であり，傾向として大きな $\mathrm{EHI}$ の領域 で F1 以上の竜巻の発生が多いことが分かる。害際の竜巻 等突風の予測にあたっては，これらの環境場の指数を用 いることにより，ポテンシャル予測ができることになる。

これらの指標のほとんどは, 上空の気温や水蒸気量, 風速の鉛直分布を用いて計算できる。このうち，EHI， VGP，STPC は，異なる物理量を表寸指標について適当 な閾值からの差を取り，それらの積を適当な定数で正規

$* 1$ 高知大学教育研究部自然科学系理学部門 教授

Professor, Research and Education Faculty Natural Sciences Cluster, Kochi University

* 2 気象研究所気象衛星観測システム研究部 研究室長

Research Head, Meteorological Research Institute,JMA

* 3 防衛大学校地球海洋学科 教授

Professor, Department of Geoscience, National Defense Academy 
化するなどしたかなりテクニカルな指標であるが，統計 的には実用性が高い。これらの指標を使うことで, 高層 気象観測データによる実況把握, 数值予報データを用い 数日前から直前までの予測に使うことができる。

気象庁が 2008 年 3 月から開始した竜巻注意情報や 2010 年 5 月から公開している竜巻ナウキャストでは, こ れらの指標等を組み合わせた回帰式を作成して発生のポ テンシャルの評価を行うとともに, 後述のメソサイクロ ン検出やレーダーエコーの強さ, 高度等の情報を加味し て，予測に利用している。ただし，これらの指標はスー パーセルに伴う竜巻については比較的良い目安となるが, 非スーパーセル竜巻や竜巻以外の突風であるダウンバー スト, ガストフロントについては異なったものが必要で ある。実際, 気象庁における竜巻注意情報等においても, 竜巻およびダウンバーストでは異なる指標と地域依存性 のある閾值を用いている。

\section{3. レーダーによる渦の探知と観測解析}

\section{1 レーダーによるメソサイクロンの探知}

ドップラーレーダーは, 積乱雲中の渦パターンを検出 することで, 竜巻の親雲となる可能性が高いスーパーセ ルを検出できる 20) 1970 年代に Burgess ら 21)はドップ ラーレーダーによるメソサイクロンの検出を行い, 約半 数で竜巻が発生していたことを見出した。上空に検出さ れる渦は, 直接に竜巻とは限らないが，間接的に竜巻の 予測ができる可能性が示されたことになる。竜巻を伴う
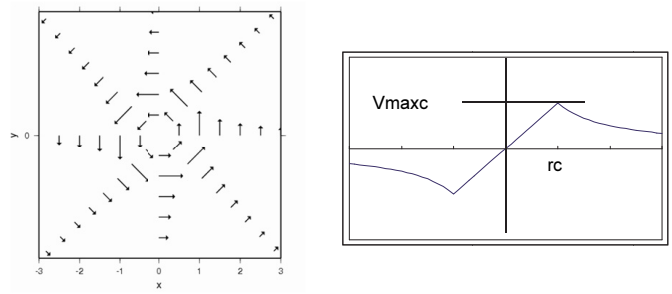

図 2 検出アルゴリズムが仮定する風の場 (Rankine 渦)

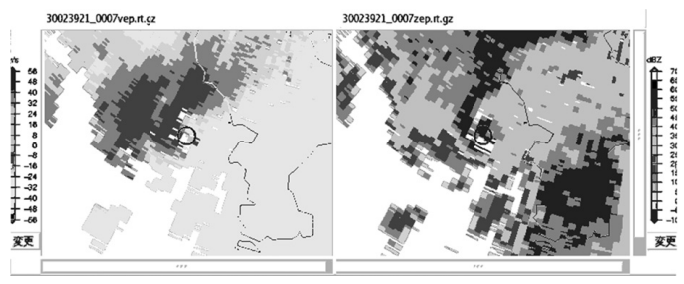

図 32003 年 9 月 30 日に羽田空港を襲った竜巻親雲中のメソサ イクロン (左 : ドップラー速度、右 : 反射強度)
メソサイクロンの割合は，最近のデータを用いた統計で は 30-50\%22)あるいは 15\%程度 23) となっているものの, 現在も最も有効な観測情報のひとつである。

これらの知見は主として米国における観測で得られた ものが多いが，我が国においてもドップラーレーダーな どを用いた研究から，スーパーセルが発生していること， 顕著な竜巻事例の多くがスーパーセルによるものである ことが分かってきた。特に, 台風に伴う竜巻の親雲とし て小振りなミニスーパーセルも多く見つかっている ${ }^{24) 。 ~}$

具体的なメソサイクロン検出アルゴリズムには種々の もの 25-27)があるが，基本的には，中心位置，渦の強さ， 剛体渦部分（コア）の直径などを求めている。

ここでは, 現在, 気象庁で使用しているドップラーレ ーダーを用いた渦検出アルゴリズムの紹介をする。検出 アルゴリズムは, メソサイクロンの渦として Rankine 渦 等を仮定し (図 2), ドップラーレーダーデータを用いて パターンマッチングによりメツサイクロンを検出する。

図3に実際の検出例を示す。図の左右は, ドップラー速 度とレーダー反射強度の場を表し, メソサイクロンは円 の部分にある。

\section{2 竜巻注意情報}

気象庁が 2008 年から開始した竜巻等突風の予測では, ドップラーレーダーによるメッサイクロンの自動検出結 果に加え, レーダーで推定した降水強度データや数值予 報モデルから前章の突風関連指数の計算結果が用いられ ており,それらを総合した突風危険指数を計算して使用

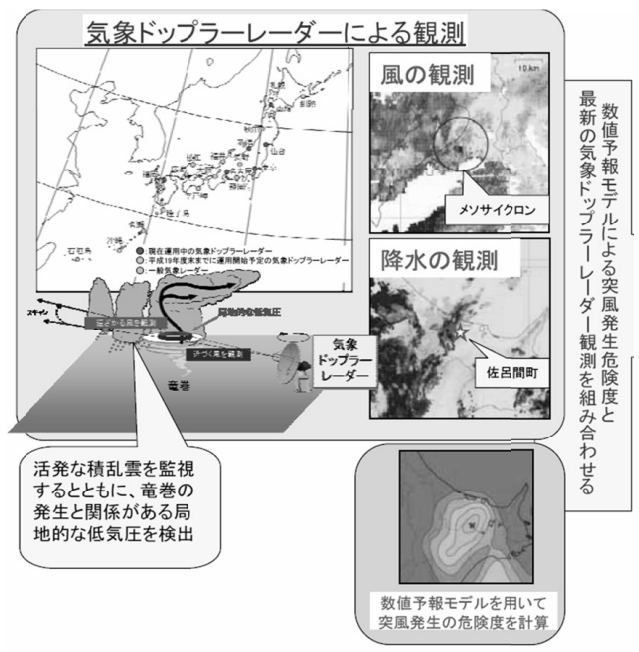

図 4 竜巻注意情報および竜巻ナウキャストのための情報生成の 模式図 


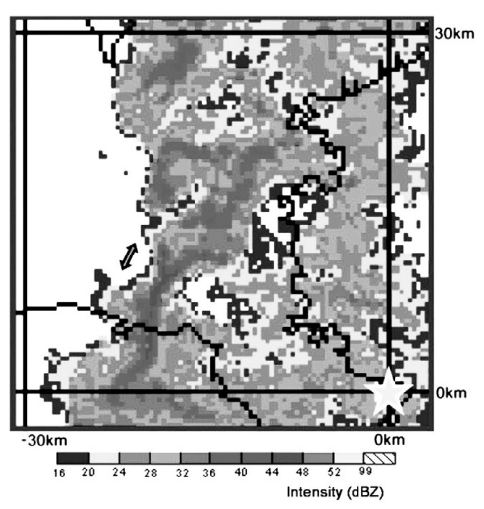

図 5 線状降水帯上に形成されたフック状エコー29

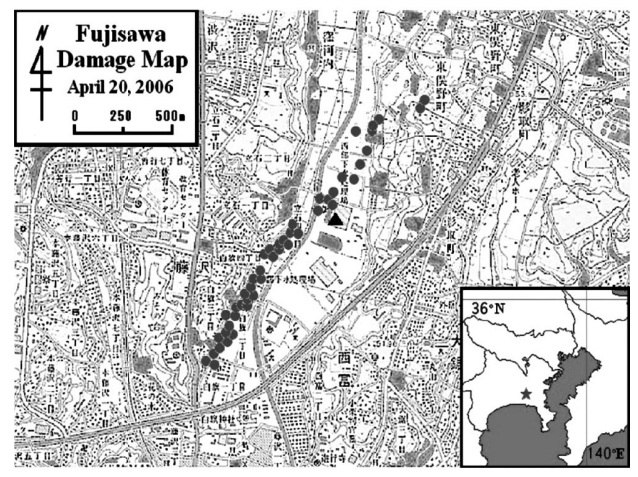

図 6 藤沢市の被害マップ32)

している ${ }^{19)}$ 。図 4 亿竜巻注意情報作成の模式図を示す。 ただし，i）非スーパーセル以外の竜巻の存在があるこ と, ii) 遠距離や小さなメソサイクロンでは必ずしもドッ プラーレーダーで捕捉されるわけではないこと，iii）必 ずしも全国がドップラーレーダーでカバーされている訳 ではないこと, iv)データ品質に起因する誤検出の存在な どの理由により, 前章の環境パラメータに基づくポテン シャル予測と組み合わせて精度向上を図っている。検出 精度については, 2010 年度において, 約 1 割の検出率で あるとされている。

\section{3 竜巻の観測事例}

日本では年間を通じて竜巻の発生が確認されており, その総観スケールでみた原因は, 温帯低気圧, 台風, 停 滞前線, 冬型 (シベリア気団), 夏型 (太平洋気団) と多 岐にわたる ${ }^{28)}$ 。実際，ドップラーレーダー観測，地上観 測と被害調查を組み合せて, 寒冷前線の線状降水帯

(Narrow Cold Frontal Rainband; NCFL) で発生した竜 巻 ${ }^{29)}$, 一様な寒気場内の日本海上で雪雲に伴って発生し

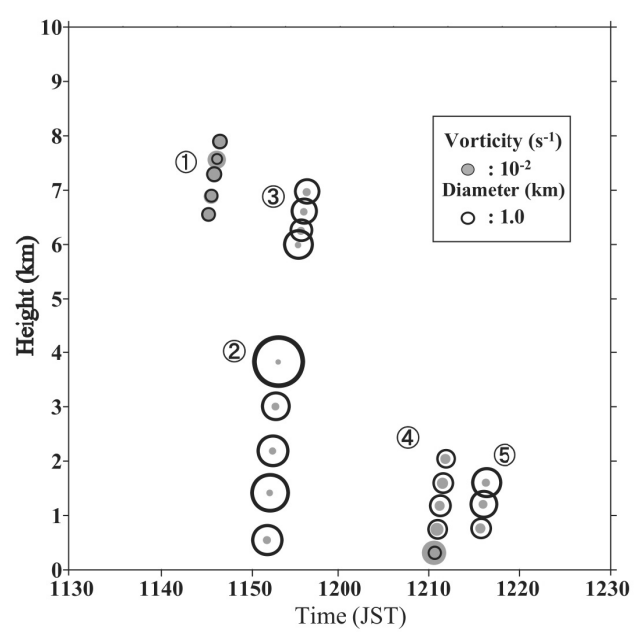

図 7 マイソサイクロンの時間高度断面図 ${ }^{33)}$

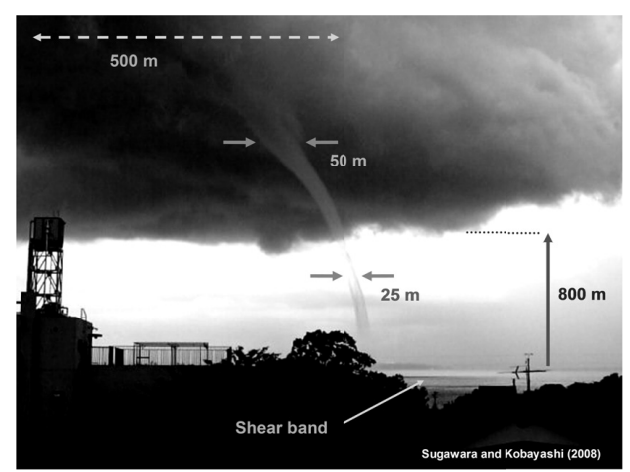

図 82007 年 5 月 31 日に東京湾で発生した竜巻 ${ }^{31)}$

た竜巻 ${ }^{30)}$, 局地的な積乱雲の発生に伴って形成された竜 巻 ${ }^{31)}$ など, 地上から雲内までの詳細な竜巻構造が報告さ れている。

図 5 は寒冷前線の線状降水帯 (NCFL) 上に複数のフッ ク状エコーが形成された事例 ${ }^{29}$ である。この事例では, 寒冷前線に沿って形成された線状のエコーが蛇行をはじ め, ついはフック状エコーがラインに沿って複数発生 した。陸上で形成されたフックエコー (図 5) は高度 $1 \mathrm{~km}$ で直径約 $5 \mathrm{~km}$ を有し, ドップラー速度場では水平方向に $2 \mathrm{~km}$ 離孔て, 遠ざかる成分と近づく成分のピーク（マイ ソサイクロン) が認められた。このフックエコー（ある いはマイソサイクロン) の直下では, フジタ・スケール で最大F1の被害が発生した。図6はこの竜巻に伴う藤沢 市の被害マップであり, 被害のスケールは被害域が長さ 2 $\mathrm{km}$, 最大幅約 $50 \mathrm{~m}$ であったことから, フジタ・ピアソン (FPP) スケールでF0-P1-P1 と結論づけられた ${ }^{32)}$

図 7 は NCFL 上で観測された，異なった 5 個のマイソサ 
イクロンの時間高度分布である。各マイソサイクロンは 1 回のボリュームスキャン内, 寸なわち 10 分未満の寿命で あった。マイソサイクロンは, 地上から高度 $2 \mathrm{~km}$ あるい は $4 \mathrm{~km}$ まで達するものと, 高度 $6 \mathrm{~km}$ から $8 \mathrm{~km}$ すなわち 雲頂付近の高高度に存在するものがあった ${ }^{33)}$ 。竜巻の親 渦が雲内のどの高度まで達しているかは, 竜巻の構造を 議論する上で重要であり, 雲内全体を高高度まで観測す る必要がある理由でもある。また, 地上付近の親渦と竜 巻のタッチダウンとの定量的な関係の解明も望まれる。

図 8 は東京湾で発生した竜巻の事例であり, 約 $10 \mathrm{~km}$ 離れたレーダサイトでは, 20 仰角のボリュームスキャン と RHI 観測を組み合わせた約 10 分の観測を連続して行い， その時間変化を捉えた ${ }^{31}$ 。この竜巻は, 周囲の積乱雲か らの下降気流の先端（ガストフロント）上で, 積乱雲の 発生とほぼ同時に形成された。このような発生過程は, waterspout のそれと類似している。竜巻発生地点におけ るレーダーの接線成分分解能は約 $100 \mathrm{~m}$ であり, 直径 $1 \mathrm{~km}$ 程度のマイソサイクロンを解像できる分解能であった。

図 9 は竜巻の鉛直分布を示したものであり, マイソサ イクロンは高度 $2 \mathrm{~km}$ 付近に直径のピーク $(1.5 \mathrm{~km})$ を持 ち, 高度 $3 \mathrm{~km}$ 以上に達していた。マイソサイクロンとは 別に竜巻渦も地上付近から高度 $3 \mathrm{~km}$ 付近まで観測された。 マイソサイクロンは, その後高度が下がるとともに直径 が増大し, 渦の崩壊 (break down) を示唆するような時 間変化がみられた ${ }^{34)}$ 。さらに, 至近距離からの動画も得 られ，海水を吸い上げて可視化された竜巻渦の構造や回 転速度も解析された ${ }^{35)}$ 。

日本では米国における巨大積乱雲（スーパーセル・ス トーム) に伴う事例のような数 10 分前から上空にメソサ イクロンが先行し, メソサイクロン内にマイソサイクロ ンと竜巻渦が形成されるマルチスケール構造を示寸竜巻 は相対的に少ない ${ }^{36)}$ 。一方, 被害強度のほとんどが F0か ら F1 である ${ }^{28)}$ ように, 非スーパーセルタイプ, すなわ ちマイソサイクロンと竜巻がほぼ同時に観測される事例

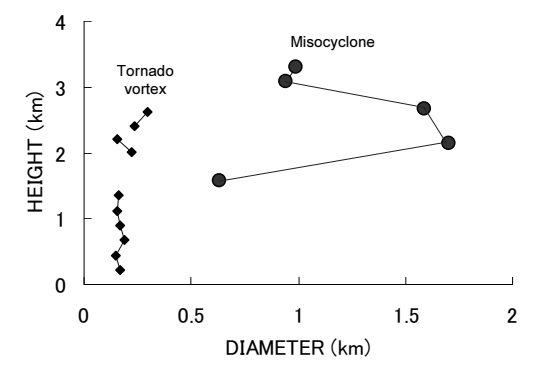

図9 竜巻渦とマイソサイクロンの直径の鉛直分布 ${ }^{31}$
が多い。さらに, 積乱雲の発生とほぼ同時にマイソサイ クロンと竜巻が形成されるこそもある。マイソサイクロ ンの寿命は 10 分未満のものが多く, ボリュームスキャン の仰角を絞って, 3 から 5 分間隔のスケジュールで観測し ても, 竜巻を解析する時間分解能としては不十分である。 図 10 は土佐湾周辺で 2008 2010 年の 3 年間のうち, 主に竜巻注意情報が出されている期間に検出されたマイ ソサイクロンの軌跡 ${ }^{37)}$ を示す。ここでは検出されるマイ ソサイクロンの内 8 割程度が土佐湾海上で発生すること がわかるが，この例や日本海側の庄内平野の観測事例 ${ }^{3)}$ が示すように, 日本の沿岸地域では竜巻は海上で発生し 上陸してくることが多い。しかし，その理由については 地域ごとに詳細な解析をしていく必要があると思われる。 なお，これらのマイソサイクロンのうち海上で発生し上 陸したものについて上陸前後の特性を比較すると, 図 11 に示すように上陸後に渦径が小さくなり渦度が強まる事

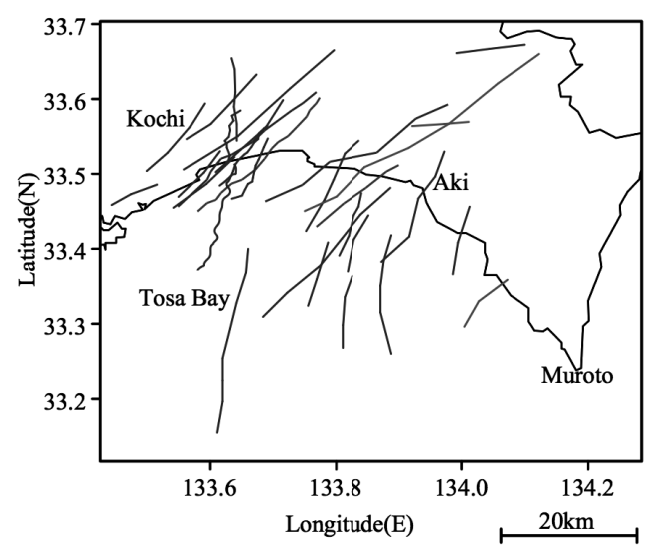

図 10 土佐湾沿岸で発生したマイソサイクロンの軌跡 ${ }^{34)}$

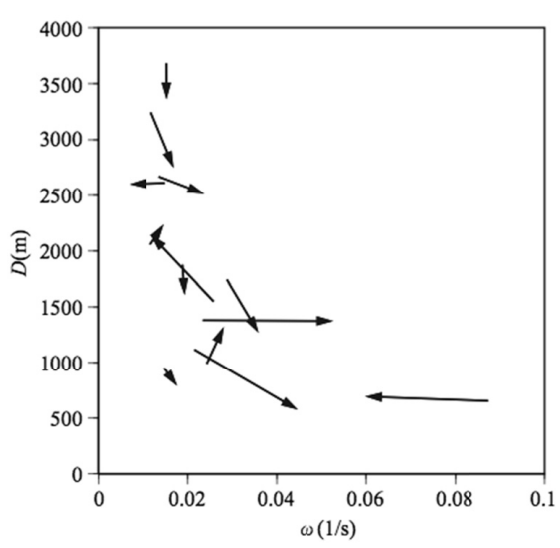

図 11 上陸前後のマイソサイクロンの渦径と渦度の変化 ${ }^{34)}$ 
例が 6 割見られた。これは地表面摩擦が逆に上陸直後の 竜巻を強化する可能性を示したものであり, 後述する気 象モデルによる事例解析の結果 ${ }^{38)}$ とは異なっている。

日本では，冬季に日本海側で発生する竜巻や突風現象 についての報告例が少なくない。しかし, 現象が小規模 で目撃が無いなどの理由で, 現象の種類やそのメカニズ ムについては不明な点も多い。これらの突風を対象とし た研究の中で, 時空間的に高密度な観測・調查を目的と して庄内平野で実施されている集中観測を紹介寸る。 Inoue ら4によると，2007 年に実施した集中観測期間 中の 12 月 2 日, 酒田市においてフジタ・スケールで Fo の竜巻が発生した。彼らは, この事例について余目駅に 設置された J R 東日本のドップラーレーダーのデータを 解析し, 海上にあった積乱雲中で $4 つ$ つイソサイクロ ンの発生を確認した。被害が起きた時間に庄内平野に上 陸した 2 つ渦の 1 つが現場を通過していたことから積 乱雲中の渦が竜巻による突風被害と関連していることを 示した。また, 2008〜2009 年の冬季に高密度な地上気象 観測網で検出された冬季の突風の9 割近くはドップラー レーダーにより渦が検出されていたことを報告している。

最近, 高谷ら ${ }^{39}$ は, BOW エコーと呼ばれる弓状の構 造を持つ対流雲 40)に伴って 2007 年 4 月 28 日東京湾岸で 発生した突風の調査を行い, BOW エコー内に発生して いた小規模の渦が突風発生の要因であることを示した。 BOW エコーは, 米国ではスーパーセルなどと並び, 突

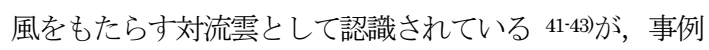
が少ないことと，ドップラーレーダーによる観測データ がまだまだ少ないこともあり，日本での認識は低い。ま た, 最近の日本海側における高密度な気象観測などで分 かってきた渦に伴う突風なじ, 新たな観測手段により, 新たな知見が見出されている。

なお, 90 年代半ば以降, 米国では最新の小型・高分解 能なドップラーレーダーや移動型の地上気象観測装置な どを用いて, 竜巻の発生を近距離で詳細に研究するため の複数の観測プロジェクトが実施されている (VORTEX $\mathrm{I}^{1}$, II 2)など)。それらの研究から, スーパーセルの発生か ら, 竜巻の発生に至るプロセスについての知見が得られ てきている。たとえばMarkowski ら ${ }^{41)}$ は, 竜巻発生の 有無に着目してスーパーセル内の気流や地上付近の気温 分布を比較し, 竜巻の渦度が上空に起源があったことや, 下降流の上空から地上への到達しや寸さの違いが, 結果 としての竜巻発生の有無に関係していたことを示した。

Wurman ら ${ }^{45)}$ は, 高分解能で可搬型ドップラーレーダー を用いて, 竜巻の風の場を解像することに成功している。

\section{4. 気象モデルによる竜巻生成メカニズムの解明}

気象モデルを用いたスーパーセルの発達過程の再現 ${ }^{4)}$ は数多く行われ，スーパーセルにおけるメソサイクロン の維持メカニズム ${ }^{6)}$ な゙゙が明らかにされてきた。近年オク ラホマ大学の開発した ARPS, NCAR などによるWRF, 気象 庁非静力学モデル NHM などを用いた空間グリッドが 50〜 $70 \mathrm{~m}$ までの高解像度シミュレーションが可能となり, スー パーセル竜巻が Rear Flank Downdraft (RFD) に伴うガスト フロント上に集中寸る鉛直渦度がメソサイクロンの上昇 流によって発達寸る様子 ${ }^{7}$ や, 延岡竜巻が図 12 に示すよ うな台風のアウターバンドで発生したスーパーセル竜巻 であり, RFDによるガストフロントの強化が竜巻発生のき っかけとなったこと ${ }^{8)}$, 佐呂間竜巻がミニスーパーセル的 な積乱雲に伴って発生したものであること ${ }^{34)}$ などを示し た。これらによりスーパーセル竜巻の発生環境や生成入 カニズムはかなり詳細に明らかになりつつある。しかし, 竜巻そのものの解像度といった点ではまだ $50 \mathrm{~m}$ のグリッ ドは十分細かいとは言えず, さらにグリッドを微細化し ていく必要がある。この場合, 大気乱流を解像できるス ケールまで微細化すると気象モデルで用いられたてきた 乱流モデルが破綻する可能性もあるため, 最も小さいグ リッドにおけるシミュレーションにおいては LES などを 用いなければならないだろう。

一方, 非スーパーセル竜巻については, 局地前線が形 成される状況から前線の収束により積雲が発達する過程 と, シアー不安定による鉛直渦度の集中域がシアーライ ン上に配列する様子を再現し, 鉛直渦度集中域のストレ

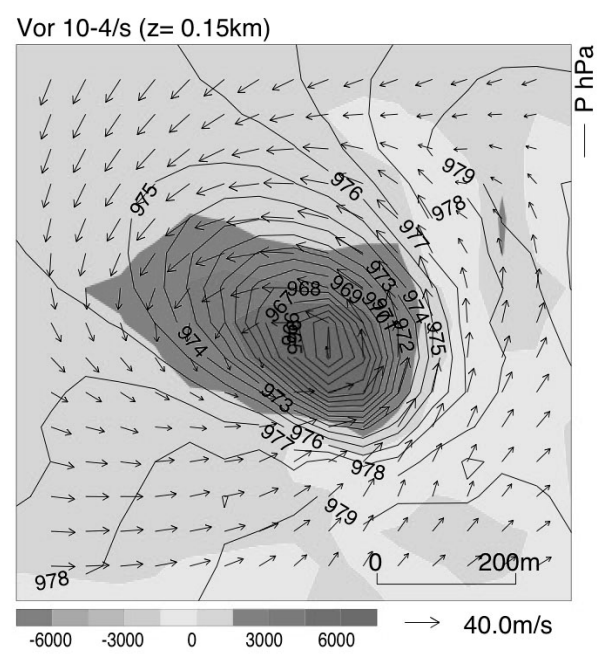

図 12 延岡竜巻の高解像度シミュレーション結果 ${ }^{8}$. 高度 $150 \mathrm{~m} に$ おける鉛直渦度, 竜巻に相対的な風ベクトル, 気圧分布 
ッチにより複数の竜巻が出来る様子 ${ }^{10}$ を明瞭に示したシ ミュレーション 5)が行われた。国内では, 庄内平野沖にお ける竜巻生成メカニズムを明らかにした雲解像非静力学 モデルであるCReSS によるシミュレーションがあり, 冬 期モンスーンに伴う浅い対流雲下で正負の渦度をもつ非 スーパーセル竜巻が形成されていく様子を明らかにした もの9)や, 海上で発生したそのようなマイソサイクロンが 上陸後地表面摩擦により減衰寸るとともに傾斜した形態 となって移動していくようすを明らかにしたNHM シミュ レーション ${ }^{46}$ などがある。これらのシミュレーションに より示された竜巻状渦は非スーパーセル竜巻の生成・発 達のメカニズムをよく表現してはいるが, 現実の竜巻に 比べるとやはり解像度の点で十分ではなく, 更なる高解 像度化が必要である。

\section{5. 室内実験による竜巻発生環境の再現}

竜巻状渦を再現する実験の多く ${ }^{47}$ は, 渦そのものの再 現によってその構造を詳細に解析寸ることに力点が置か れており，鉛直渦の旋回を案内羽根などによって強制的 に作り出している。大気中のような自由空間中でいかに 竜巻が生成されるかを再現する実験 ${ }^{48}$ は数少なく, 気象 モデルに頼るのが一般的である。しかし，大気中の基本 的な流れ場を模擬することができれば，降水システムそ のものの再現ができなくても竜巻の生成を再現すること は可能である。

非スーパーセル竜巻については積乱雲から降下して地 表面付近を流れる冷気外出流をドライアイスミストで, 積乱雲の上昇気流をファンでそれぞれ模擬することによ り, 図 13 のように容易に竜巻状渦の生成を再現すること

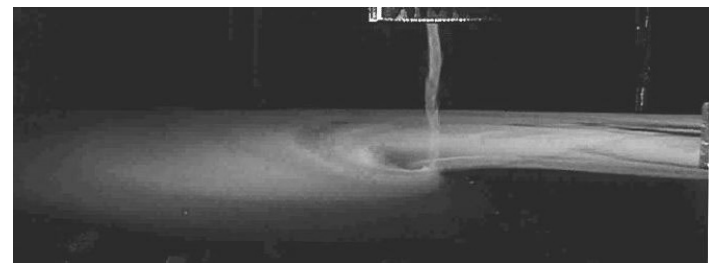

（a）親雲移動速度が遅い場合

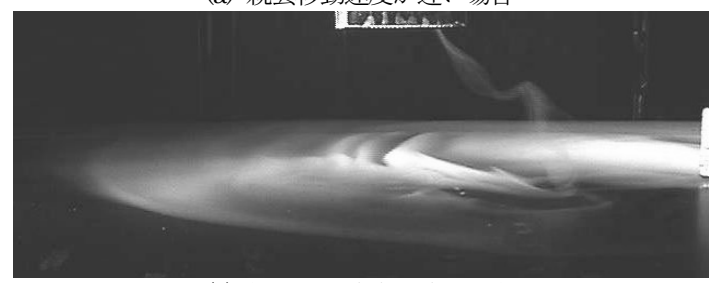

（b）親雲移動速度が速い場合

図 13 非スーパーセル竜巻の模擬実験 49)
ができる。この際, ドライアイスミストで模擬された冷 気外出流の端が鉛直渦度を多く含む水平シアーの場であ り，これを上昇流により引き延ばすことでストレッチン グメカニズムにより竜巻状渦が生成される。このときの 回転方向は, 鉛直渦度の符号に依存して反時計回転にも 時計回転にもなり得る。親雲の移動速度が比較的遅い場 合は図 13(a)のように床面に垂直な竜巻状渦が形成され るが, 移動速度が速くなると地表面摩擦により下層の渦 が追従できなくなるため図 13(b)のように渦が傾斜し, や がて渦がちぎれて消滅する。この様子は実際の竜巻の消 失過程によく似ている。一方, 冷気外出流の鉛直シアー を上昇流により引き上げると, ティルティングメカニズ ムによる鉛直渦の生成も図 14 に示寸ように冷気外出流 と上昇流を模擬するだけで再現可能である。これは, スー パーセル内にメソサイクロンが発生するときの生成モデ ル 50)を忠実に再現したものであり，これまで概念モデル として捉えられてきた生成メカニズムが実験により実証 された。さらに冷気外出流の流れと地形との干渉につい て再現実験を行うことも可能である。図 15 は北海道佐呂 間町の南側の谷地形を南から流入する気流を模擬するこ とによって再現した佐呂間竜巻の様子 51)を示す。この実 験を通して, 佐呂間竜巻の生成には観測事実や数值モデ ルの解析 34) と同様に西方からのガストと南側の谷からの

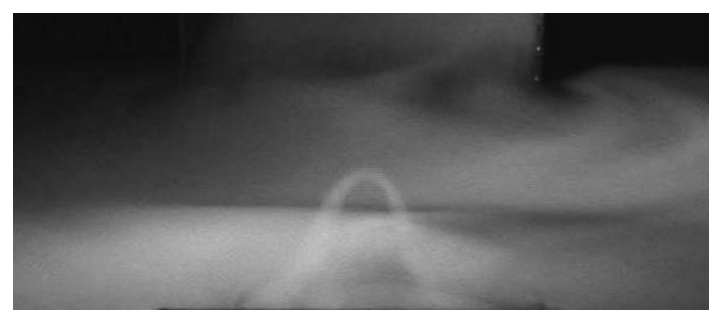

図 14 鉛直シアーの水平渦からティルティングにより生成され る鉛直渦 49$)$

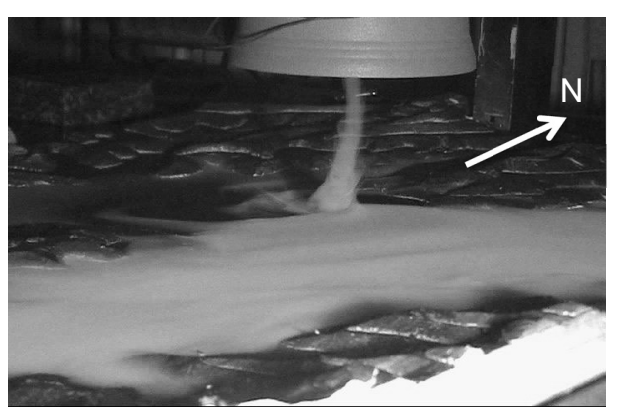

図 15 佐呂間竜巻の再現実験 51$)$ 
暖気の流入が寄与していることが確認された。ただし，

ドライアイスミストにより再現可能な冷気相出流の流速 や厚さは制御することができないため, 厳密な地形との 干渉実験を行うには, 制御可能な冷気外出流模擬装置が 必要となる。

スーパーセルの流れ環境として重要なものは, 強い回 転上昇流であるメソサイクロンとスーパーセル背面側か らの強い降水とともにおりてくる RFD による地表面付 近のガストフロント 7,52)である。これらを再現するスーパ 一セル模擬装置 48)においても RFD の泠気外出流は非ス ーパーセル竜巻の場合と同様にドライアイスミストを用 いた。一方, メソサイクロンの回転上昇流は従来の竜巻 シミュレーター53) と同様に上部にファンと底に案内羽根 をもつ対流胴からなるメソサイクロン模擬装置を使用寸 るが, 従来のシミュレーターと大きく異なるのは, メソ サイクロン模擬装置が地表面から少し浮かせて設置され, 地表面付近の気流は案内羽根の影響を受けること無く自 由に流入できることである。図 16 に再現されたスーパー セル竜巻の例として, 逆回転する渦(図 16a) と多重渦(図 16b)の様子を示す。メソサイクロンは反時計回転をして おり，それと逆方向の回転を持つ竜巻が生成されること は, メソサイクロンの回転そのものが下層の竜巻生成に あまり寄与しない可能性を示すものである。一対の逆回 転する渦が生成される様子は実際のスーパーセル竜巻に おいても観測 54)されている。また, 多重渦も現実のスー パーセル竜巻において観測 55)されている。従来の室内実 験では下層から竜巻状渦に流入する気流をできるだけ層 流に近い状態にするよう工夫したシミュレーターのみで 再現されてきた多重渦が，本スーパーセル模擬装置では 容易に安定して生成させることができた。これらの流れ パターンはメソサイクロン模擬装置の案内羽根の迎角と 底部の高度に依存して変化し, 条件によっては全く竜巻 状渦が生成されない場合もある。このことは, レーダー 観測によってメソサイクロンが検出されるスーパーセル であっても竜巻を生成しない場合がある 22,23)ことに対応 している。このことは，降水過程などを含まない流れ環 境の夕に限定されるものの, 竜巻を発生させるスーパー セルの環境場の特徵を理解する糸口を示寸ものである。

\section{6. まとめと今後の展望}

竜巻研究の現状においては, スーパーセルに伴う竜巻 の理解は，米国を中心とする高分解能なドップラーレー ダ一や地上気象観測, 高分解能な数值予報モデルなどを 用いた研究により大きく進んだ。そのなかで，対流雲内

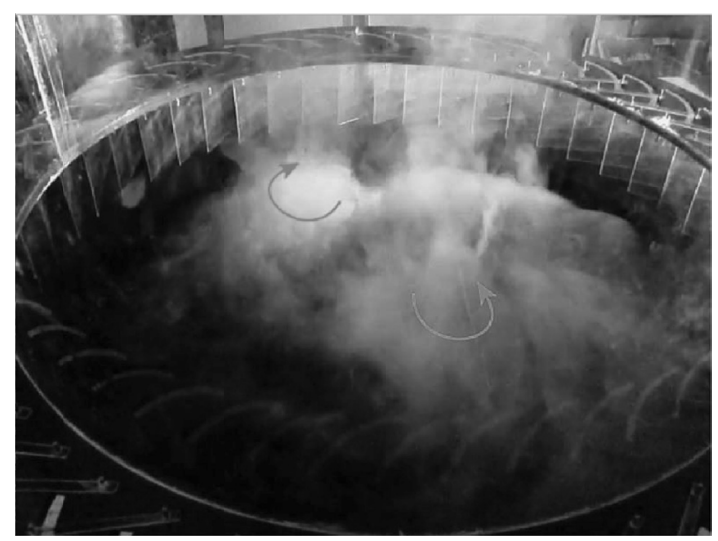

(a) 互いに逆回転する一対の渦

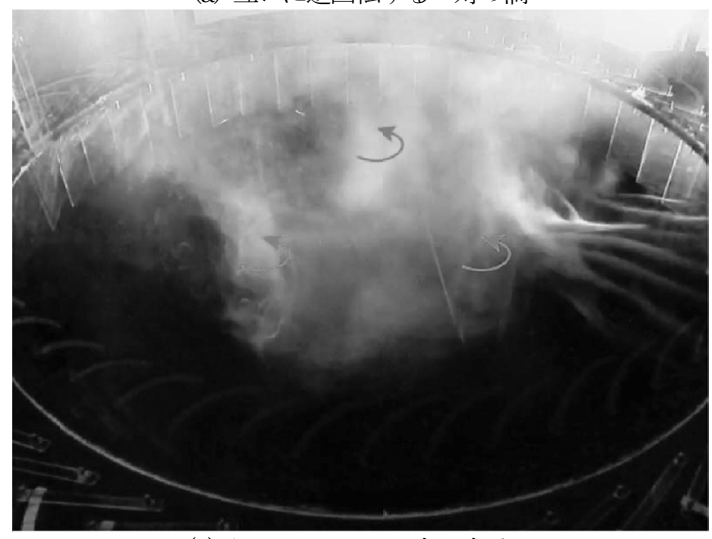

(b)吸い込み渦を 3 つ含む多重渦

図 16 スーパーセル竜巻模擬装置により再現された渦 ${ }^{48}$

の下降流の挙動の重要性が見出されている。日本におい ても 2006 年の延岡竜巻や佐呂間竜巻をきっかけとして 観測や気象モデルによる研究は大きく進展し, 気象庁が ドップラーレーダーを整備して竜巻注意情報を出す実用 段階に達した。しかし, 親雲内の上空の渦度がどのよう に最終的に地上付近の竜巻を発生させるのかか, 竜巻を 伴う場合とそうでない場合のメソサイクロンの違いはな んなのか, などについては今後の課題である。また, 非 スーパーセルを始めとして, 予測の的中率はまだ低く, さらなるブレークスルーも必要と思われる。

\section{付録 主な指標の定義}

A 1.CAPE $[\mathrm{J} / \mathrm{kg}]$ の計算式

$$
C A P E=\int_{L F C}^{E L} g \frac{T v^{\prime}(z)-T v(z)}{T v(z)} d z
$$

$\mathrm{g}:$ 重力加速度。

$T v$ : 環境（状態曲線）の仮温度。気温を $\mathrm{T}$, 比湿を $\mathrm{q}$ とし $T v=(1+0.622 q) T$ 
$T v^{\prime}$ : 湿潤断熱的に上昇したときの空気の仮温度

CAPE の非積分関数は, 上昇する気塊と周囲の空気と の密度差による浮力に関する項である。空気の密度は, 気温と水蒸気量, 気圧の関数であるが, 気温と水蒸気量 により定義される仮温度を定義すると, 密度は気圧と仮

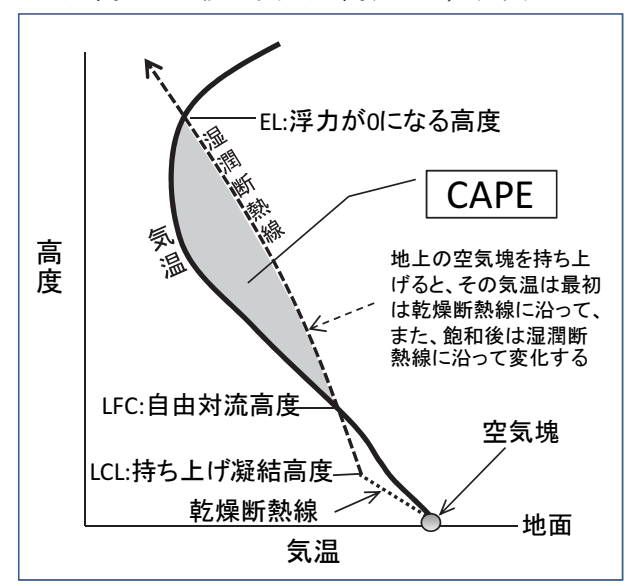

付図 1 CAPE を求める大気温度の鉛直分布図

温度のみの関数となる。

A 2. SRH $[\mathrm{m} 2 / \mathrm{s} 2]$ の計算式

$$
\begin{gathered}
S R H=\int_{\text {也上 }}^{\text {高度 } 3 \mathrm{~km}}(\mathbf{v}(z)-\mathbf{c}) \cdot \omega_{H}(z) d z \\
\omega_{H}=\left(-\frac{\partial v}{\partial z}, \frac{\partial u}{\partial z}\right) \quad: \text { 鉛直シアによる水平渦度。 } \\
\boldsymbol{v}=(u, v) \quad: \text { 水平風ベクトル。 } \\
\mathbf{c} \quad: \text { 積乱雲の水平移動ベクトル。 }
\end{gathered}
$$

\section{A 3. EHIの計算式}

$$
E H I=\frac{C A P E \times S R H}{160000}
$$

160000 は，正規化のための定数。

\section{参考文献}

1) Rasmussen E. N., Ed., and Coauthors, 'VORTEX1995 operations plan,' National Severe Storms Laboratory, Norman, OK. (1995) 141pp.

2) Bluestein H. B., Burgess D., Dowell D., Markowski E., Rasmussen E., Richardson Y., Wicker L. and Wurman J., 'Verification of the origins of rotation in tornadoes experiment', preprints, 5tth European Conference on Severe Storms, Landshut, Germany, (2009) O09-06, 2pp.
3) Inoue H., Kusunoki K., Kato W., Suzuki H., Imai T., Takemi T., Bessho K., Nakazato M., Hoshino S., Mashiko W., Hayashi S., 'Finescale Doppler Radar Observation of a Tornado and Low-Level Misocyclones within a Winter Storm in the Japan Sea Coastal Region', Mon. Wea. Rev., (2011) 351-369.

4) Wicker L. J. and Wilhelmson R. B., 'Simulation and analysis of tornado development and decay within a three-dimensional supercell thunderstorm', J. Atmos. Sci., 52 (1995) 2675-2703.

5) Lee B. D. and Wilhelmson R. B., 'The numerical simulation of nonsupercell tornadogenesis. Part II: Evolution of a family of tornadoes along a weak outflow boundary', J. Atmos. Sci. 54 (1997) 2387-2415.

6) Klemp, Joseph B., Richard Rotunno, 'A Study of the Tornadic Region within a Supercell Thunderstorm. J. Atmos. Sci, 40, (1983) 359-377.

7) Noda A. and Niino H., 'A numerical investigation of a supercell tornado: genesis and vorticity budget', J. Meteor. Soc. Japan, 88, (2010) 135-159.

8) Mashiko W., Niino H. and Kato T., Numerical Simulation of Tornadogenesis in an Outer-Rainband Minisupercell of Typhoon Shanshan on 17 September 2006,'Mon. Wea. Rev., 137 (2009) 4328-4260.

9) Tsuboki, K. and Sakskibara, A., Numerical simulation of tornado-scale vortices occurred in a winter cold-air outbreak over the Sea of Japan,' preprints, The 5th European conference on severe storms, Landshut, Germany (2009) 181-182.

10)Wakimoto R. M. and Wilson J. W., 'Non-supercell tornadoes,' Mon. Wea. Rev., 117 (1989) 1113-1140.

11)Darkow, G. L., 'An analysis of over sixty tornado proximity soundings,' Preprints, 6th Conference on Severe Local Storms, Chicago, Amer. Meteor. Soc., (1969) 218-221.

12) Maddox, R. A., 'An Evaluation of Tornado Proximity Wind and Stability Data,' Mon. Wea. Rev., 104 (1976) 133-142.

13) Browning, K. A., 'Airflow and precipitation trajectories within severe local storms which travel to the right of the winds,' J. Atmos. Sci., 21 (1964) 634-639.

14) Davis, J. M., 'Hourly helicity, instavility, and EHI in forecasting supercell tornadoes,' Preprints, 17th Conf. on Severe Local Storms, St. Louis, MO, 
American Meteorological Society, (1990) 107-111.

15) Davies-Jones, R. P., Burgess, D. And Foster, M.,

'Test of helicity as a tornado forecast parameter,' Preprints, 16th Conf. on Severe Local Storms, St Louis, MO, American meteorological Society, (1990) 585-592.

16) Nakazato, M., O. Suzuki, K. Kusunoki, H. Yamauchi and H. Inoue, 'Possible stretching mechanisms producing the tornado vortex in the mid-level,' Proc. of 13th Conf. on Mesoscale Processes, (2009) P1.7.

17) Rasumussen E. N., and R. B. Wilhelmson, 'Relationship between storm characterisitics and 12 GMT hodographs, low-level shear, and stability, Preprints, 13th Conf. on Sever Local Storms, Tlsa, OK, Amer. Meteor. Soc., (1983) J5-J8.

18) Thompson, R. L., R. Edwards, J. A. Hart, K. L. Elmore, and P. Markowski, 'Close proximity soundings within supercell environments obtained from the Rapid Update Cycle,' Wea. Forecasting, 18 (2003) 1243-1261.

19)海老原智, 瀧下洋一, 突風予測技術, 平成 19 年度 量的予報研修テキスト，気象庁予報部 (2007) 1-16。

20)Donaldson,R.J., 'Vortex signature recognition by a Doppler radar,' J. Appl. Meteor., 9 (1970) 661-670.

21) Burgess, D., R. J. Donaldson, T. Sieland, and J. Hinkelman, 'Final Report on the Joint Doppler Operational Project (JDOP 1976-1978). Part I: Meteorological Applications,' NOAA Tech. Memo. ERL NSSL-86, NOAA, Boulder, CO, (1979) 84 pp.

22) Burgess, D. W., and L. R. Lemon, 'Characteristics of meso-cyclones detected during a NEXRAD test,' Preprints, 25th Int. Conf. on Radar Meteorology, Paris, France, Amer. Me-teor. Soc., (1991) 39-42.

23) Trapp, R. J., Stumpf, G. J. and Manross, K. L., 'A Reassessment of the Percentage of Tornadic Mesocyclones,' Weather and Forecasting, 20-4 (2005) 680-687.

24)Suzuki, O., H. Niino, H. Ohno and H. Nirasawa, 'Tornado-Producing Mini Supercells Associated with Typhoon 9019,' Mon. Wea. Rev., 128 (2000) 1868-1882.

25)Wieler, J. G. 'Real-Time Automated Detection of Mesocyclones and Tornadic Vortex Signatures,' J. of Atmos. and Ocea. Tech. 3 (1986) 98-113.
26)Zrnic', D. S., D. W. Burgess, and L. D. Hennington, 'Automatic detection of mesocyclonic shear with Doppler radar,' J. Atmos. Oceanic Technol., 2 (1985) 425-438.

27)Stumpf, J. G., A. Witt, E. D. Mitchell, P. L. Spencer, J. T. Johnson, M. D. Eilts, K. W. Thomas, and D. W. Burgess, 'The National Severe Storms Laboratory mesocyclone detection algorithm for the WSR-88D,' Wea. Forecasting, 13 (1998) 304-326.

28) 小林文明，菅原祐也，松井正宏，最近 10 年間のわが 国における竜巻の統計的特徵, 日本風工学会誌, 32 (2007) 155-156.

29) Kobayashi, F., Y. Sugawara, M. Imai, M. Matsui, A. Yoshida and Y. Tamura, Tornado generation in a narrow cold frontal rainband -Fujisawa tornado on April 20, 2006-', SOLA, 3 (2007) 21-24.

30) Kobayashi, F., Y. Sugimoto, T. Suzuki, T. Maesaka and Q. Moteki, 'Doppler radar observation of a tornado generated over the Japan Sea coast during a cold air outbreak,' J. Meteor. Soc. Japan, 85 (2007) 321-334.

31) Sugawara, Y. and F. Kobayashi, 'Structure of a waterspout occurred over Tokyo Bay on May 31, 2007,' SOLA, 4 (2008) 1-4.

32) 小林文明, 菅原祐也, 今井真希, 松井正宏, 吉田昭仁, 田村幸雄, ‘2006 年 4 月 20 日に発生した藤沢竜巻の 被害特性, ’ 日本風工学会誌, 32 (2007), 265-272.

33) Sugawara, Y. and F. Kobayashi, 'Vertical struc' ture of misocyclones along a Narrow Cold Frontal Rainband,' J. Meteor. Soc. Japan, 87 (2009) 497-503.

34)小林文明，菅原祐也，' 2007 年 5 月 31 日東京湾で発 生した竜巻とマイソサイクロンの関係, 第20回風工 学シンポジウム論文集 (2008) 151-156.

35) 小林文明，菅原祐也，今井真希，前坂剛，2007 年 5 月 31 日に千葉県富津沖で発生した竜巻の風速分布, 日本風工学会論文集, 33（2008）45-50.

36) Kobayashi, F., K. Kikuchi and H. Uyeda, 'Life cycle of the Chitose tornado of September 22, 1988,' J. Meteor. Soc. Japan, 74( 1996) 125-140.

37) Sassa, K., I. Hamada, Y. Hamaguchi and T. Hayashi, 'Characterisitics of misocyclones observed on Tosa Bay in Japan,' Preprints, The 6th European Conference on Severe Storms, Palma de 
Mallorca, Spain, (2011) 2pp.

38) Simose, S. et al., Numerical simulation of low-level misocyclones associated with winter convective cells: a case study from the Shonai area railroad weather project', preprints,' Preprints, The 25th Severe local storms, Denver, U.S.A. (2010) P10.15, 3pp.

39) 高谷美正, 鈴木修, 山内洋, 中里真久, 猪上華子, '2007 年 4 月 28 日東京湾岸地帯で発生した突風 Bow Echo の解析的研究, 天気, 58.12 (2011) 1037-1054.

40) Fujita T. T., 'The downburst', Satellite and Mesometeorology Research Project (SMRP), Dept. of Geophysical Science, University of Chicago (1985) 122pp.

41) Przybylinski, R. W., 'The Bow Echo: Observations, Numerical Simulations, and Severe Weather Detection Methods,' Wea. Forecasting, 10 (1995) 203-218.

42)Wakimoto, R. M., H. V. Murphey, A. Nester, D. P. Jorgensen, N. T. Atkins, 'High Winds Generated by Bow Echoes. Part I: Overview of the Omaha Bow Echo 5 July 2003 Storm during BAMEX,' Mon. Wea. Rev., 134 (2006) 2793-2812.

43)Wakimoto, R. M., H. V. Murphey, C. A. Davis, N. T. Atkins, 'High Winds Generated by Bow Echoes. Part II: The Relationship between the Mesovortices and Damaging Straight-Line Winds,' Mon. Wea. Rev., 134 (2006) 2813-2829.

44)Markowski, P. M., J. M. Straka, E. N. Rasmussen,2003:Tornadogenesis Resulting from the Transport of Circulation by a Downdraft: Idealized Numerical Simulations, J. Atmos. Sci. 60, pp. 795-823.

45)Wurman, J., K. Kosiba, P. Markowski, Y. Richardson, D. Dowell and P. Robinson, 'Finescale Single- and Dual-Doppler Analysis of Tornado Intensification, Maintenance, and Dissipation in the Orleans, Nebraska, Supercell,' Mon. Wea. Rev. 138, (2010) 4439-4455.

46)加藤輝之, 新野宏, “佐呂間の竜巻の発生環境に関す る研究, 平成 18 年度科学研究費補助金 (特別研究促 進費) 課題番号 18900003 研究成果報告書「北海道佐 呂間町で発生した竜巻による甚大な災害に関する調 查研究」, (2007) 15-31.
47) Monji N., 'Laboratory studies of tornado vortices', CIMMS report, (1980) 55pp.

48)佐々浩司, ‘竜巻の発生環境を再現寸る実験,’ なが れ, 30 (2011) 395-400.

49)佐々浩司，“鉛直軸を持った渦の再現実験,’ 京都大 学防災研究所一般共同研究集会 18K-02, (2006) 20-23.

50)Klemp J. B., 'Dynamics of tornadic thunderstorms,' Ann. Rev. Fluid Mech. 19 (1987) 369-402.

51)佐々浩司, 林泰一, 現地調查と模擬実験に基づく佐呂 間竜巻発生時の大気下層場の推定, 平成 18 年度科学 研究費補助金 (特別研究促進費) 課題番号 18900003 研究成果報告書「北海道佐呂間町で発生した竜巻によ る甚大な災害に関する調查研究」，(2007) 39-51.

52)Lemon L. R. and Doswell III, C.A., 'Severe thunderstorm evolution and mesocyclone structure as related to tornadogenesis', Mon. Wea. Rev., 107 (1979) 1184-1197.

53) Church C. R., Snow J. T. and Agee E. M. A., 'Tornado vortex simulation at Purdue university,' Bull. Amer. Meteor. Soc., 58 (1977) 900-908.

54) Brown J. M. and Knupp K. R., "The Iowa cyclonicanticyclonic tornado pair and its parent thunderstorm,' Mon. Wea. Rev. 108 (1980) 1626-1646.

55)Wurman J., 'The Multiple-Vortex Structure of a Tornado,'Wea. Forecast. 17 (2002), 473-505. 